\title{
Role of Organizational Psychology in Dealing with Human Resources and the Performance of the Organizations
}

\author{
Nasrin Khalfan Al-Abri, Ruqaya Fayiz Al-Sharji, Maryam Said Al-Arimi, \\ Ahlam Khater Al-Fahdi, Muanis Mohamed Al-Zadjal, Nirmala Roy* \\ Department of Business Studies, University of Technology and Applied Sciences (HCT), Muscat, Sultanate of Oman \\ Email: *drnirmalaroy@gmail.com
}

How to cite this paper: Al-Abri, N.K., Al-Sharji, R.F., Al-Arimi, M.S., Al-Fahdi, A.K., Al-Zadjal, M.M. and Roy, N. (2021) Role of Organizational Psychology in Dealing with Human Resources and the Performance of the Organizations. Open Access Library Journal, 8: e7928.

https://doi.org/10.4236/oalib.1107928

Received: September 6, 2021

Accepted: October 10, 2021

Published: October 13, 2021

Copyright () 2021 by author(s) and Open Access Library Inc.

This work is licensed under the Creative Commons Attribution International License (CC BY 4.0).

http://creativecommons.org/licenses/by/4.0/

(c) (i) Open Access

\begin{abstract}
Organizational psychology focuses mainly on taking care of corporate interests and the needs of employees. This seeks to provide a better life and better conditions for employees in their companies to help them be more productive and effective in their organization. This article focuses on how the organization is practicing the psychology of training and motivation for the growth of the organization. This study was undertaken with the employees working in different organizations. The main focus is how organizational psychology creates an impact on the performance of the organization. The sample size for the study is 40 employees and the researcher used descriptive research. Non-random sampling method was used and the data was collected through convenience sampling techniques. The primary data was collected from the respondents through the questionnaire. In this research, many participants agreed that motivation and training affect the employees' performance. The outcomes revealed that organizational psychology has many roles in the participants' organizations such as increasing the performance, the productivity, the efficiency of the employees and many others.
\end{abstract}

\section{Subject Areas \\ Human Resource Management \\ Keywords \\ Organizational Psychology, Motivation, Training}

\section{Introduction}

Around the world, there are significant numbers of people with several beha- 
viors, attitudes, shapes, minds and cultures. All these differences can affect humanity and society in different circumstances. On the other hand, those differences can lead to making a change in the people themselves. The change can be positive which can develop and improve the person's personality and may affect the society and organizational industries in many points. Employees' psychology is an important thing that can make any organization successful. Organizations must study and get knowledge about what their employees are good at to improve their performances. All those represent important roles in employee's performance. This research is to explore the roles of organizational psychology in dealing with human resources in the workplace (Figure 1).

\subsection{Statement of the Problem}

Nowadays organizations became more familiar with the importance of organizational psychology more than before. Training and motivation can affect employees' performance positively. This research aims to discuss the roles of organizational psychology in dealing with human resources in organizations. Also, its purpose is to examine the effect of motivation and training in organizational psychology and employee's performance.

\subsection{Objectives and Goals of the Research}

The objectives and goals of the research is to explore the roles of organizational psychology in organizations, to examine the effect of motivation and training in organizational psychology and employee's performance and to offer suggestions for improving performance in the workplace through organizational psychology.

\subsection{Scope of the Study}

This study will cover several important points of view which talk about the roles of organizational Psychology in dealing with human resources in organizations. In addition, how the organizations can deal with different types of employees if the organization wants to recruit new employees and who is the best candidate that can work with the organization's teams easily in the workplace. Thus, the goal of this study is to explore the reasons how the organizations psychology can help them to deal with old and new employees and the ability to cope up with any change in the organization. Moreover, all organizations need to introduce new ways of psychology to make a good change in employee's minds, attitudes,

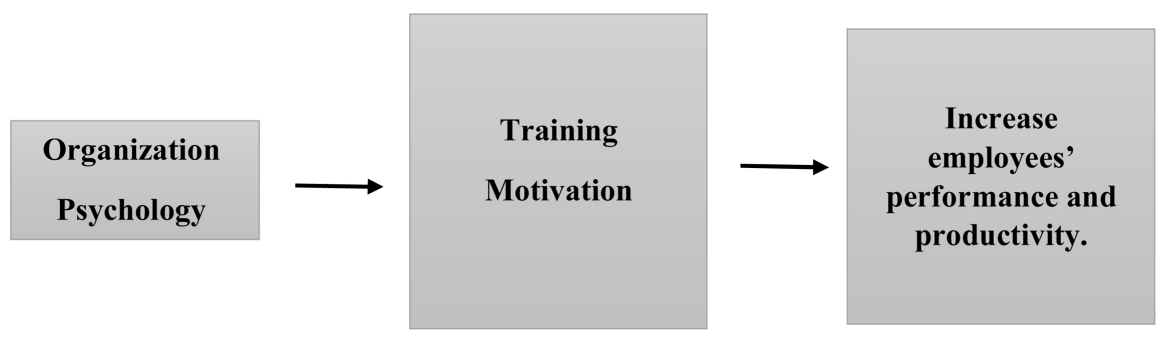

Figure 1. Conceptual framework. 
and behaviors.

\subsection{Definition of Terms}

Human resource behavior: Behaviors and attitudes of employees within the company and their level of satisfaction, commitment, and performance in the company (Rowe, 2019) [1].

Human resource: It is the workforce that is made up of a group of people in an organization (Kenton, 2020) [2].

Organization behavior: The methods and behaviors that the employee interacts with within the groups and how he deals with the different circumstances within the company (Kopp, 2021) [3].

Organization psychology: It is a science concerned with studying the internal cases of individuals related to job topics and how employees within the organization interact with each other as it facilitates individual and organizational effectiveness through work design and organizational structure (Cherry, 2019) [4].

Positive organization behavior: A system that studies the positives of the strength of human resources and psychological capabilities that can be measured and applied within the institution (Arora, 2012) [5].

\section{Related Literature}

\subsection{To Identify the Main Organizational Psychology in Organization}

Human resources are extremely important to the effectiveness of an organization, and they must be managed properly and effectively. There is a relationship between understating human behaviors at the workplace and employee development. (Reis, Collndins and Berscheid, 2000) [6].

As individuals, to feel confident and build relationships, they need to experience autonomy. Therefore, when all these basic needs of individuals are met, there will be improvement in human well-being and satisfaction. This will be reflected in the effectiveness of his work performance. (Sahoo, Gupta and Shivahare, 2018) [7].

It ranks employees as the most important stakeholders in the effectiveness of the organization. One of the characteristics that make organizations more sustainable in the world is the way they behave towards the employees. There are responsibilities such as organizations must direct their employees to identify their behaviors. Resources are divided into two parts: a tangible section and an intangible section that organizations can improve performance effectiveness and productivity. Personnel, internal culture, motivation and employee training are intangible resources. This perspective helps organizations to understand human resource behavior and employee morale, loyalty, motivation, and commitment to the organization (Obrad and Gherhes, 2019) [8].

Bajwa and König (2019) [9], revealed that organizational psychology is an important subfield. Workplace issues facing employees and some organizations 
are discussed using theories and principles. The field of organizational psychology has become more prevalent among countries due to its importance in the workplace, as organizational psychology helps in improving performance and efficiency.

\subsection{To Examine the Effect of Motivation and Training in Organizational Psychology and Employee's Performance}

According to (Khan, 2012) [10], the aim of this study is to illustrate the effect of training on employee's efficiency. Education, motivation, technology, management behavior, and the working environment are all factors that contribute to overall employees' performance. Employees' relative importance is one of the most important contributing factors. In contrast to other variables such as motivation, technology, management behavior, and working climate, this study concludes that has a major effect on employees' performance. Employee's success, preparation, and motivation all have a positive relationship. Training and motivation influence employee's success, according to the report. According to the finding of this study, organizations with good employees training programs will improve employee's efficiency. Training should be a priority for any company aiming to increase employee's efficiency because it motivates workers to reach higher standards of performance.

According to (Elnaga \& Imran, 2013) [11], Employees are the most valuable assets of any company because through employees a company can create its reputation, or it can affect the company negatively. Employees are responsible for the part of the work related to customer satisfaction and product quality and without proper training they will not be able to do their job to the fullest. Training and motivation are very necessary for the workplace, as it affects the performance of employees and through it, the employees will have a strong understanding of their responsibilities and duties. Because of the technological development in the current era, companies must train their employees to obtain the required capabilities and competencies and they must motivate them to perform because all these factors affect the performance of the employee. In the absence of appropriate training and motivation, employees will become frustrated because they cannot understand how to properly perform their tasks due to insufficient knowledge to perform them, and this affects their performance.

\subsection{To Offer Suggestion for Improving the Performance in the Workplace through Organizational Psychology}

For decades, extensive longitudinal studies have been conducted on the relationship between individual level organizational engagement and employee efficiency. Even though available theory suggests that involvement has a greater impact at the unit level, few studies have looked at the effects of collective organizational engagement on performance. They show you how it has done. The findings show that unit-level organizational engagement is statistically linked to unit-level performance quality and unit-level performance quality. The total 
amount of time customers spent with tellers at service counters was unrelated to mutual organizational involvement or the absence of unit-level employees. (Nakahara, Mukai and Kubo, 2012) [12].

According to (Suklum, 2014) [13], Creativity is a very important organizational resource for organizational performance, enhancing the creativity of employees is the key to any organization. Since psychological well-being and creativity are two related factors, people who do not have psychological well-being factors such as hope, and happiness will become difficult for them to be creative within the organization.

The well-being of employees is one of the important factors that every organization must take into consideration, As the environment of neglect plays an important and essential role in the general well-being of employees, which in turn affects their performance within the organization and then on their productivity. People who have a better life represent $50 \%$ only if they are satisfied with their work environment (Kour, Den and Sriratanaviriyakul, 2019) [14].

\section{Methodology}

\subsection{Reserch Method}

This study is focusing more on contributions and the impacts of organizational psychology on human resource inside the firms. The population is a universe; it is not focusing on a specific organization. Few of private and public organizations in Oman are randomly selected for gathering the data. The sample size is likely to be 40 that will be selected randomly based on systematic random sampling. The primary data was collected from respondents through structured questionnaire. Respondent of the study was employees from private and public organizations.

\subsection{Type of Reserch}

The research used in this study is descriptive research. And this research is a quantitative research. The quantitative research is a procedure for gathering and analyzing numerical information. It can be used to look for trends and averages, make forecasts, test causal relationships, and extrapolate findings to larger groups (Bhandari, 2020) [15]. However, the qualitative research is entailing the gathering and analysis of non-numerical data to comprehend ideas, viewpoints, or past observations. It can be used to gain in-depth understanding of an issue or to create new research ideas (Bhandari, 2020) [16].

\section{Analysis}

\subsection{Results}

From Table 1, it is observed that that practicing organizational psychology in the organization lead to success of the organization. $40 \%$ of the respondents strongly agree, $57.5 \%$ agree and $2.3 \%$ were partly agree/partly disagree that practicing organizational psychology in the organization lead to success of the organization. 
Table 1. To what extent practicing organizational psychology in the organization leads to success of the organization.

\begin{tabular}{ccccc}
\hline No & No. of & $\begin{array}{c}\% \text { of } \\
\text { respondents }\end{array}$ & $\begin{array}{c}\text { Cumulative } \\
\text { frequency }\end{array}$ \\
\hline 1 & Strongly Agree & 16 & $40 \%$ & 16 \\
2 & Agree & 23 & $57.5 \%$ & 39 \\
3 & Partly Agree/Partly Disagree & 1 & $2.5 \%$ & 40 \\
4 & Disagree & 0 & $0 \%$ & 0 \\
5 & Strongly Disagree & 0 & $0 \%$ & 40 \\
Total & & 40 & $100 \%$ & \\
\hline
\end{tabular}

Source: Primary data.

From Table 2, it is known that training the employees effectively act the employee's performance. $45 \%$ of the respondents strongly agree, 50\% agree and 5\% Partly agree/Partly disagree that training the employees effectively act the employee's performance.

From Table 3, respondents agree that Lack of training in organizations leads to low efficiency. $45 \%$ of the respondents strongly agree, $45 \%$ agree and $10 \%$ Partly agree/Partly disagree that Lack of training in organizations leads to low efficiency.

From Table 4, the respondents agree that lack of motivation and training affect the state of the organization. $52.5 \%$ of the respondents strongly agree, $35 \%$ agree, $10 \%$ partly agree/partly disagree and $1 \%$ disagree that lack of motivation and training affect the state of the organization.

From Table 5, the respondents agree that organizational psychology helps in improving employee efficiency. $25 \%$ of the respondents strongly agree, $70 \%$ agree and 5\% partly agree/partly disagree that organizational psychology helps in improving employee efficiency.

From Table 6, the relationship between the management and the employee's helps in building a good workplace environment. 57.5\% of the respondents strongly agree, $32.5 \%$ agree and $10 \%$ partly agree/partly disagree with the relationship between the management and the employee's help in building a good workplace environment.

From Table 7, it was understood that the respondents agree that organizational psychology encourages teamwork. $27.5 \%$ of the respondents strongly agree, 52.5\% agree and $17.5 \%$ Partly agree/Partly disagree and $2.5 \%$ disagree that organizational psychology encourages teamwork.

From Table 8, the respondents agree that organizational psychology helps in achieving the goals of the organization. $30 \%$ of the respondents strongly agree, $52.5 \%$ agree, $15 \%$ partly agree/partly disagree and $2.5 \%$ strongly disagree that organizational psychology helps in achieving the goals of the organization. 
Table 2. To what extent training the employees effectively affect the employee's performance.

\begin{tabular}{ccccc}
\hline No & No. of & $\begin{array}{c}\% \text { of } \\
\text { respondents }\end{array}$ & $\begin{array}{c}\text { Cumulative } \\
\text { frequency }\end{array}$ \\
\hline 1 & Strongly Agree & 18 & $45 \%$ & 18 \\
3 & Partly Agree/Partly Disagree & 20 & $50 \%$ & 38 \\
4 & Disagree & 2 & $5 \%$ & 40 \\
5 & Strongly Disagree & 0 & $0 \%$ & 40 \\
Total & & 0 & $0 \%$ & $40 \%$ \\
\hline
\end{tabular}

Source: Primary data.

Table 3. Lack of training in organizations leads to low efficiency.

\begin{tabular}{|c|c|c|c|c|}
\hline No & & $\begin{array}{c}\text { No. of } \\
\text { respondents }\end{array}$ & $\begin{array}{c}\% \text { of } \\
\text { respondents }\end{array}$ & $\begin{array}{l}\text { Cumulative } \\
\text { frequency }\end{array}$ \\
\hline 1 & Strongly Agree & 18 & $45 \%$ & 18 \\
\hline 2 & Agree & 18 & $45 \%$ & 36 \\
\hline 3 & Partly Agree/Partly Disagree & 4 & $10 \%$ & 40 \\
\hline 4 & Disagree & 0 & $0 \%$ & 40 \\
\hline 5 & Strongly Disagree & 0 & $0 \%$ & 40 \\
\hline Total & & 40 & $100 \%$ & \\
\hline
\end{tabular}

Source: Primary data.

Table 4. Lack of motivation affecting the states of the organization.

\begin{tabular}{ccccc}
\hline No & No. of & $\begin{array}{c}\% \text { of } \\
\text { respondents }\end{array}$ & $\begin{array}{c}\text { Cumulative } \\
\text { frequency }\end{array}$ \\
\hline 1 & Strongly Agree & 21 & $52.5 \%$ & 21 \\
3 & Partly Agree/Partly Disagree & 14 & $35 \%$ & 39 \\
4 & Disagree & 4 & $10 \%$ & 40 \\
5 & Strongly Disagree & 1 & $2.5 \%$ & 40 \\
Total & & 0 & $0 \%$ & $100 \%$ \\
\end{tabular}

Source: Primary data.

From Table 9, it is known that the respondents agree that organizational psychology influences increasing employee's performance. $42.5 \%$ of the respondents strongly agree, $52.5 \%$ agree and $5 \%$ partly agree/partly disagree that organizational psychology influences increasing employee's performance. 
Table 5. Psychology helps in improving employee efficiency.

\begin{tabular}{ccccc}
\hline No & No. of & $\begin{array}{c}\% \text { of } \\
\text { respondents }\end{array}$ & $\begin{array}{c}\text { Cumulative } \\
\text { respondents }\end{array}$ & \begin{tabular}{c} 
frequency \\
\hline 1
\end{tabular} \\
2 & Strongly Agree & 10 & $25 \%$ & 10 \\
3 & Agree & 28 & $70 \%$ & 38 \\
4 & Partly Agree/Partly Disagree & 2 & $5 \%$ & 40 \\
5 & Disagree & 0 & $0 \%$ & 40 \\
Total & Strongly Disagree & 0 & $0 \%$ & 40 \\
\hline
\end{tabular}

Source: Primary data.

Table 6. Relationship between the management and the employees helps in building a good work environment.

\begin{tabular}{ccccc}
\hline No & No. of & $\begin{array}{c}\% \text { of } \\
\text { respondents }\end{array}$ & $\begin{array}{c}\text { Cumulative } \\
\text { frequency }\end{array}$ \\
\hline 1 & Strongly Agree & 23 & $57.5 \%$ & 23 \\
2 & Agree & 13 & $32.5 \%$ & 36 \\
3 & Partly Agree/Partly Disagree & 4 & $10 \%$ & 40 \\
4 & Disagree & 0 & 0 & 40 \\
5 & Strongly Disagree & 0 & 0 & 40 \\
Total & & 40 & $100 \%$ & \\
\hline
\end{tabular}

Source: Primary data.

Table 7. To what extent, organizational psychology encourages teamwork.

\begin{tabular}{ccccc}
\hline No & No. of & $\begin{array}{c}\text { \% of } \\
\text { respondents }\end{array}$ & $\begin{array}{c}\text { Cumulative } \\
\text { respondents }\end{array}$ & 11 \\
\hline 1 & Strongly Agree & 11 & $27.5 \%$ & 32 \\
2 & Agree & 21 & $52.5 \%$ & 39 \\
4 & Partly Agree/Partly Disagree & 7 & $17.5 \%$ & 40 \\
5 & Disagree & 1 & $2.5 \%$ & 40 \\
Total & Strongly Disagree & 0 & $0 \%$ & \\
\hline
\end{tabular}

Source: Primary data.

Table 8. Organizational psychology helps in achieving the goals of the organization.

\begin{tabular}{rcccc}
\hline No & No. of & $\begin{array}{c}\% \text { of } \\
\text { respondents }\end{array}$ & $\begin{array}{c}\text { Cumulative } \\
\text { frequency }\end{array}$ \\
\hline 1 & Strongly Agree & 12 & $30 \%$ & 12 \\
2 & Agree & 21 & $52.5 \%$ & 33 \\
3 & Partly Agree/Partly Disagree & 6 & $15 \%$ & 39 \\
4 & Disagree & 0 & $0 \%$ & 39 \\
5 & Strongly Disagree & 1 & $2.5 \%$ & 40 \\
Total & & 40 & $100 \%$ & \\
\hline
\end{tabular}

Source: Primary data. 
Table 9. Organizational psychology in organization increases employee's performance.

\begin{tabular}{ccccc}
\hline No & Strongly Agree & $\begin{array}{c}\text { No. of } \\
\text { respondents }\end{array}$ & $\begin{array}{c}\% \text { of } \\
\text { respondents }\end{array}$ & $\begin{array}{c}\text { Cumulative } \\
\text { frequency }\end{array}$ \\
\hline 1 & Agree & 21 & $42.5 \%$ & 17 \\
2 & Partly Agree/Partly Disagree & 2 & $52.5 \%$ & 38 \\
3 & Disagree & 0 & $5 \%$ & 40 \\
4 & Strongly Disagree & 0 & $0 \%$ & 40 \\
5 & & 40 & $0 \%$ & 40 \\
Total & & & $100 \%$ & \\
\hline
\end{tabular}

Source: Primary data.

\subsection{The Most Common Responds toward the Roles of Organizational Psychology in Workplace of the Participants}

- Organizational psychology helps the organizational performance since the employees perceived that when the employees have great states of mental health that can help them to be more productive in the workplace and can allow them to focus on their work.

- Motivation through organizational psychology can improve their workers' well-being and increase efficiency and productivity in the workplace.

- Motivating in organizational psychology brings Satisfaction to their employees and raises their productivity and teamwork.

- It helps to solve the problems and obstacles that appear in the work environment efficiently and effectively.

- Raising employees' morale.

- Motivating employees while taking care of their psychological state.

\section{Suggestions}

Based on the findings we suggest this recommendation which is to improve the organizational psychology in organizations and to clarify the importance of knowing the roles of organizational psychology in dealing with human resources and performance in the organizations. We recommend organizational psychology in organizations to intensify and develop training to improve employee's performance and to motivate employees while taking care of their psychological state.

- The Organization should work hard in improving organizational psychology to achieve the goals easily.

- The company should improve the training program to increase the employee's motivation.

- Motivating employees with promotions, allowances, and other material matters.

- Providing psychological care to employees when needed.

- Appreciating and reinforcing the workers.

- Listening to employees' complaints so that responsible in organizational psy- 
chology can solve problems quickly, and can lead to increase the employee's work efficiency.

- Because people are ashamed to go to psychiatry, the importance of psychology must be clarified and included in the educational, educational curricula and provided in the workplace.

We recommend researchers do further research on the following topics:

1) More research is needed to identify effective ways of improving organizational psychology in the workplace.

2) Ways to educate people about the importance of organizational psychology in the organizations.

\section{Conclusions}

The purpose of the project was to identify the roles of organizational psychology in organization and examine the effect of motivation and training in organizational psychology and employee's performance. It is concluded that organizational psychology is important in organization, and it has many important roles. As founded that Organization psychology helps to improve the productivity and efficiency of the employees. Also, it can provide psychological care to the employees. Also, it is concluded that motivation and training increase performance. As founded, a lot of participants agreed that lack of motivation effects on the state of organizations negatively. Also, many participants agreed that training effectively affects the employee's performance.

When workers feel fine and everything is good in the working climate, they can produce more and maintain very good quality. This is where organizational psychology, represented in companies by the Department of Human Resources and Personnel Affairs, is represented in companies. Its main role is to create the necessary factors and conditions that help improve the organization's environment and stimulate productivity. He also serves as an intermediary that combines the organization's interests with those of workers.

\section{Conflicts of Interest}

The authors declare no conflicts of interest.

\section{References}

[1] Rowe, R.H. (2019) Organizational Behavior \& Human Resource Theories. Small Business, Chron.com.

https://smallbusiness.chron.com/organizational-behavior-human-resource-theories $-74260 . \mathrm{html}$

[2] Kenton, W. (2020, August 28) Human Resources (HR). Investopedia. https://www.investopedia.com/terms/h/humanresources.asp\#: :text=Human\%20re sources $\% 20$ (HR)\%20is\%20the,as\%20administering\%20employee $\% 2$ Dbenefit $\% 20 \mathrm{pr}$ ograms

[3] Kopp, C.M. (2021, March 16) Organizational Behavior (OB) Definition. Investopedia. https://www.investopedia.com/terms/o/organizational-behavior.asp 
[4] Cherry, K. (2019, November 26) How Industrial-Organizational Psychology Helps Improve Workplaces. Verywell Mind.

https://www.verywellmind.com/what-is-industrial-organizational-psychology-2795 $\underline{302}$

[5] Arora, T. (2012, April 8) Positive Organizational Behaviour. SlideShare. https://www.slideshare.net/tushar1707/positive-organizational-behaviour

[6] Reis, H., Collins, W. and Berscheid, E. (2000) The Relationship Context of Human Behavior and Development. Psychological Bulletin, 126, 844-872. https://doi.org/10.1037/0033-2909.126.6.844

[7] Sahoo, B., Gupta, A. and Shivahare, B. (2018) Audio Visual EMG \& GSR Biofeedback Analysis and Spiritual Methods for Understanding Human Behaviour and Psychosomatic Disorders. Amity Journal of Computational Sciences, 2, 33-39.

[8] Obrad, C. and Gherhes, V. (2019) Human Resources Perspective on Responsible Corporate Behavior. Case Study: The Multinational Companies in Western Romania. Sustainability, 10, 726. https://doi.org/10.3390/su10030726

[9] Bajwa, N. and König, C. (2019) How Much Is Research in the Top Journals of Industrial/Organizational Psychology Dominated by Authors from the U.S.? Scientometrics, 120, 1147-1161. https://doi.org/10.1007/s11192-019-03180-2

[10] Khan, M. (2021) The Impact of Training and Motivation on Performance of Employees. Papers.ssrn.com. https://papers.ssrn.com/sol3/papers.cfm?abstract_id=2206854

[11] Elnaga, A. and Imran, A. (2013) The Effect of Training on Employee Performance. European Journal of Business and Management, 5, 137-147.

[12] Nakahara, S., Mukai, Y. and Kubo, A. (2012) Synthesis of Neoamphimedine. Heterocycles, 85, 933. https://doi.org/10.3987/COM-12-12440

[13] Suklum, H. (2014) Macro Think Institute. Employees' Psychological Performance. From (PDF) Employees' Psychological Performance (researchgate.net). 14-15.

[14] Kour, J., El-Den, J. and Sriratanaviriyakul, N. (2019) The Role of Positive Psychology in Improving Employees' Performance and Organizational Productivity: An Experimental Study. Procedia Computer Science, 161, 226-232. https://doi.org/10.1016/j.procs.2019.11.118

[15] Bhandari, P. (2020) An Introduction to Quantitative Research. https://www.scribbr.com/methodology/quantitative-research

[16] Bhandari, P. (2020) What Is Qualitative Research? Methods \& Examples. https://www.scribbr.com/methodology/qualitative-research 